Article

\title{
Adoption and Income Effects of Public GAP Standards: Evidence from the Horticultural Sector in Thailand
}

\author{
Henning Krause ${ }^{1, *}$, Rattiya Suddeephong Lippe ${ }^{2}$ and Ulrike Grote ${ }^{1}$ \\ 1 Institute for Environmental Economics and World Trade, Leibniz Universität Hannover, \\ Königsworther Platz 1, 30167 Hannover, Germany; grote@iuw.uni-hannover.de \\ 2 Institute of Development and Agricultural Economics, Leibniz Universität Hannover, Königsworther Platz 1, \\ 30167 Hannover, Germany; lippe@ifgb.uni-hannover.de \\ * Correspondence: krause@iuw.uni-hannover.de; Tel.: +49-511-762-19567
}

Academic Editors: Marco A. Palma and Douglas D. Archbold

Received: 18 July 2016; Accepted: 14 November 2016; Published: 21 November 2016

\begin{abstract}
To reduce potential food hazards and increase the image of Thai horticultural products abroad, the Thai government introduced public standards of Good Agricultural Practices (Q-GAP). What makes orchid and mango producers in Thailand adopt Q-GAP standards and how do these affect their income and export shares? Primary data from 400 certified and non-certified orchid and mango producers was collected from main exporting provinces in Thailand. The binary probit model estimations show that it is the orchid and mango producers with higher education, and more physical and social capital who tend to comply with Q-GAP standards. Results from the Propensity Score Matching approach reveal that adoption of public GAP standards results in positive income effects for mango producers, but not for orchid producers. This can be explained by the fact that certified mango producers can sell their products to high-value retail chains which offer higher prices for their products, while certified and non-certified orchid producers cooperate with traders from the same value chain.
\end{abstract}

Keywords: Good Agricultural Practice; mango; orchid; Thailand; income impacts; Heckman model; Propensity Score Matching

\section{Introduction}

The demand for fresh horticultural products is continually rising, both in domestic and international markets [1]. Consumers from industrialized countries, such as some countries in the European Union, desire the year-round availability of a variety of horticultural products including tropical fruits and flowers [2]. In response to these trends, the interest in accessing these markets has significantly increased among producers and traders of horticultural products in developing countries. However, a more frequent occurrence of food safety problems and the rising health consciousness of consumers have led to an increasing demand for safe horticultural products [3]. At the same time, consumers have increasingly paid attention to environmental concerns and the way food is being produced including its farming practices. In addition, there was a gradual shift from concerns about only edible goods to other agricultural goods, such as flowers or timber products.

The scope of national legislation in many developing countries is considered insufficient for transnational trade [4]. Thus, trade liberalization and globalization in the last decades have resulted in institutional adaptation, driving the development of internationally recognized standards and regulatory schemes [5]. Standards and certification systems which define whether products have been produced in an environmentally-friendly way or whether they are free of pesticides are considered as viable solutions to sort out the problem of information asymmetry and reduce transaction costs among 
different actors in the supply chain [6]. Certification systems also help to increase the communication between actors in the supply chain on production processes. Similarly, labeling is a form of directly conveying information of quality aspects of the product to end consumers [7].

In global horticultural value chains, private actors, such as big supermarkets and/or retail chains, play an increasingly large role. They have become rule-setters and often take the initiative to ensure certain safety and quality levels and create market demand for exotic produce [8]. Good Agricultural Practices (GAP) are food safety and quality standards of on-farm and post-farm activities, encompassing a set of management regulations of how to produce environmentally friendly and socially-acceptable products [9]. GAPs are the most important standards in global horticultural value chains and they have been especially promoted by the private sector initiative GLOBALG.A.P. However, the trend towards private GAP standards still poses many challenges as compliance can be a rather complex task; it also involves high investment costs and additional skilled laborers. As a result, producers without appropriate financial resources are not likely to adopt those private standards [10]. In contrast to private GAP standards, public GAP certification schemes are introduced by governments in export-oriented emerging nations. They are based on their own quality and safety standards to position themselves in competitive global markets [11]. They can also be an alternative for export-oriented producers due to lower cost of compliance and lower complexity of its schemes. Besides the easier access for the individual producers, public GAP standards can be a way of adding value to the country's agricultural goods for export as a whole [12]. The empowerment of public standards is often the only necessary step to unleash the potential of exporting horticultural goods [13,14]. To enhance export growth, some developing countries have already successfully upgraded their export sectors through better compliance with the increasing public food standards in global markets [15].

The Thai government follows the long-term strategy to expand Thai exports of horticultural products [16]. Thai authorities have actively promoted voluntary public Q-GAP standards ( $Q$ denotes quality) as part of their strategy to maintain and expand export markets. The aim of this scheme is to assure product quality and compliance with certain environmental and social regulations [3,16]. A full implementation of the national GAP program (Q-GAP) started in 2004, as an important component in the road map of food safety policy [16,17]. The national Q-GAP standards contain eight principles (water source, cultivation site, use of agro-chemicals, product storage and on-site transportation, data records, pest-free products, quality management, harvesting and post-harvest handling) and to date emphasize pesticide control and Maximum Residue Limits (MRLs) monitoring. Producers are allowed to label their produce with the golden Q-mark if they comply with all required principles. The entire certification process is carried out by government agencies [16]. In this regard, costs of compliance, specifically for training, external auditing and the annual certification fee, are mostly covered by government agencies and are thus free for producers. However, producers still have to cover other costs of upgrading their facilities (i.e., farm infrastructure and equipment such as storage room for pesticides) and buying protective clothing for farm workers [10].

While the number of certified producers in the horticultural food sector is growing, recently the non-food sector (i.e., flowers) has shown a reduction in Q-GAP adoption rates [18]. It is therefore questionable whether producers do benefit from complying with this public scheme. However, only a small number of in-depth analyses exist in the context of public GAP standards and for the horticulture sector in general. Up to the point of this study, no impact analysis from a public GAP certification scheme on income could be found. This study therefore aims at assessing the determinants of adopting a public GAP standard among producers of horticulture products and the standard's impact on producers' income and export shares by focusing on mango and orchids as representative for food and non-food horticultural products.

Orchid and mango were chosen due to their economic importance and high export potential to overseas markets [19]. The advantage of comparing orchids and mangoes is that they are rather similar in terms of their presence in Thai domestic and international markets. While they are both 
rather common products in domestic markets bought by everyone, they are also exported in large quantities [19]. This allows us to draw conclusions from the results focusing only on the aspect of edible vs. inedible horticultural crops. The problems that producers of edible horticultural products face when they want to enter the export market are quite different to the ones that producers of inedible goods like flowers face. Food safety, for example, is a major concern for producers of fresh edible horticultural products, while for inedible crops quality aspects, such as the appearance, are more important. It is thus questionable if producers of these two types of products have similar adoption patterns for the same certification program. We expect that the standards in the certification program, which are identical for mango and orchid producers, will have different effects because of the different needs among producers and the demand of consumers of edible and inedible horticultural crops.

This study will help Thai government officials and other actors in the Q-GAP administration to evaluate the success of the program and seek strategies to enhance it. Next to the Thai government, all governmental and non-governmental agencies which design or plan to design certification schemes are expected to benefit from this study. They will be more aware about the factors that drive producers to adopt certain schemes but they will be also informed about the impact of the schemes in terms of income and export facilitation.

The paper is structured as follows. The next section gives an overview of the current adoption and impact literature for standards and certification in horticultural products, followed by the conceptual framework. Data collection and methodology are presented in the third section. The last section concludes with a summary of the main results of the study and highlights the need for further empirical research.

\section{Literature Review}

\subsection{The Impact of Certification on Horticultural Producers' Welfare}

In spite of the rapid integration of developing countries into the global horticultural markets, not all producers and exporters could fulfill demands from markets associated with standards and certification compliance. Previous studies mainly focused on the impact of private standards and certification on individual producers [20-22]. For instance, certified Brazilian producers receive a higher net income due to the price premium for their certified products in contrast to those who are not certified. Besides increasing income levels, other benefits of compliance relate to environmental, health, food safety aspects and higher productivity [22]. EurepGAP-certified Turkish producers have been found to sell their tomatoes at a higher price, having a net income which is around 2.8 times higher per unit area compared to non-certified ones. The adoption rate of EurepGAP certification even accelerates if producers already exhibit experience with the certification system [21]. Another example is Kenya, where EurepGAP producers could significantly improve their financial performance by exporting certified vegetables. Further benefits from compliance are long-term relations with their buyers, maintaining the share in lucrative export markets, or increased awareness of agrochemical handling practices [20]. However, complying with standards and certifications entails some costs, such as an increase in investment costs due to production inputs, facilities and additional labor needs. In that sense, it is likely that small-scale producers are unable to comply with the emerging standards, increasing the probability of their exclusion from lucrative export markets $[1,20,23-25]$.

To the knowledge of the authors, no study exists that analyses the direct impact of public GAP schemes on producers' income. However, several studies investigated some benefits of these schemes for the farmers. Thai Mangosteen producers following the Q-GAP scheme stated that they did not receive a direct price premium for the certified product, but they could increase their share of high-quality fruits and this way achieved higher prices [26]. Furthermore, exporters preferred business links with Q-GAP certified farmers and this way Q-GAP facilitated the export of Mangosteen, even though the production costs were higher due to the increased need for labor [26]. In contrast to this, Q-GAP was not demanded in the Thai domestic coffee market and thus participation of coffee farmers 
was low [27]. Other hampering factors were that requirements were considered too complicated and the frequency of inspections was low, which shed doubt on the reliability of the scheme among the farmers [27]. VietGAP is a public GAP scheme rather similar to the Thai Q-GAP scheme, which has been implemented by the Vietnamese government. After receiving training for VietGAP implementation, Vietnamese citrus producers found that they could reduce input costs and increase yield and quality thanks to the implemented standards [28]. The VietGAP program was also found to reduce health hazards from the spraying of harmful pesticides [29]. This way, the farmers were not only healthier thanks to the scheme, but they also significantly reduced their loss of income [29].

\subsection{Conceptual Framework}

International trading companies often demand quality assurance systems such as Q-GAP from producers of agricultural products [26]. Currently, Q-GAP is the most important and recognized public scheme for export-oriented Thai horticultural products. Implementing the Q-GAP scheme could thus facilitate the access to high-value export markets. Especially if implementation and recurring costs of the certification are low, as in the case of Q-GAP, selling their products at a higher price than the domestic market will lead to a higher household income for orchid and mango producers. The impact of Q-GAP certification is thus evaluated through the direct change in income from mango and orchid production and the share of mangoes and orchids sold to the high-value/export market.

The present study focuses on the impact of these standards and the decision process of compliance, based on the five-stage innovation decision model from Rogers [29]. The adoption of a certification program can be considered an innovation aiming to differentiate products [30]. Rogers [31] states that certain household characteristics and the expected benefits of the certification scheme influence the adoption decision (Figure 1). Based on the livelihood framework of Scoones [32], the farm decision maker will decide to adopt certification depending on the livelihood assets available [33]. According to this framework, demographic factors, human resource factors, physical capital, social capital and public infrastructure have an influence on the adoption decision [32]. These five dimensions of livelihood assets and the results of empirical adoption literature up to this point thus guide the variable choices for the model describing the adoption process of Q-GAP.

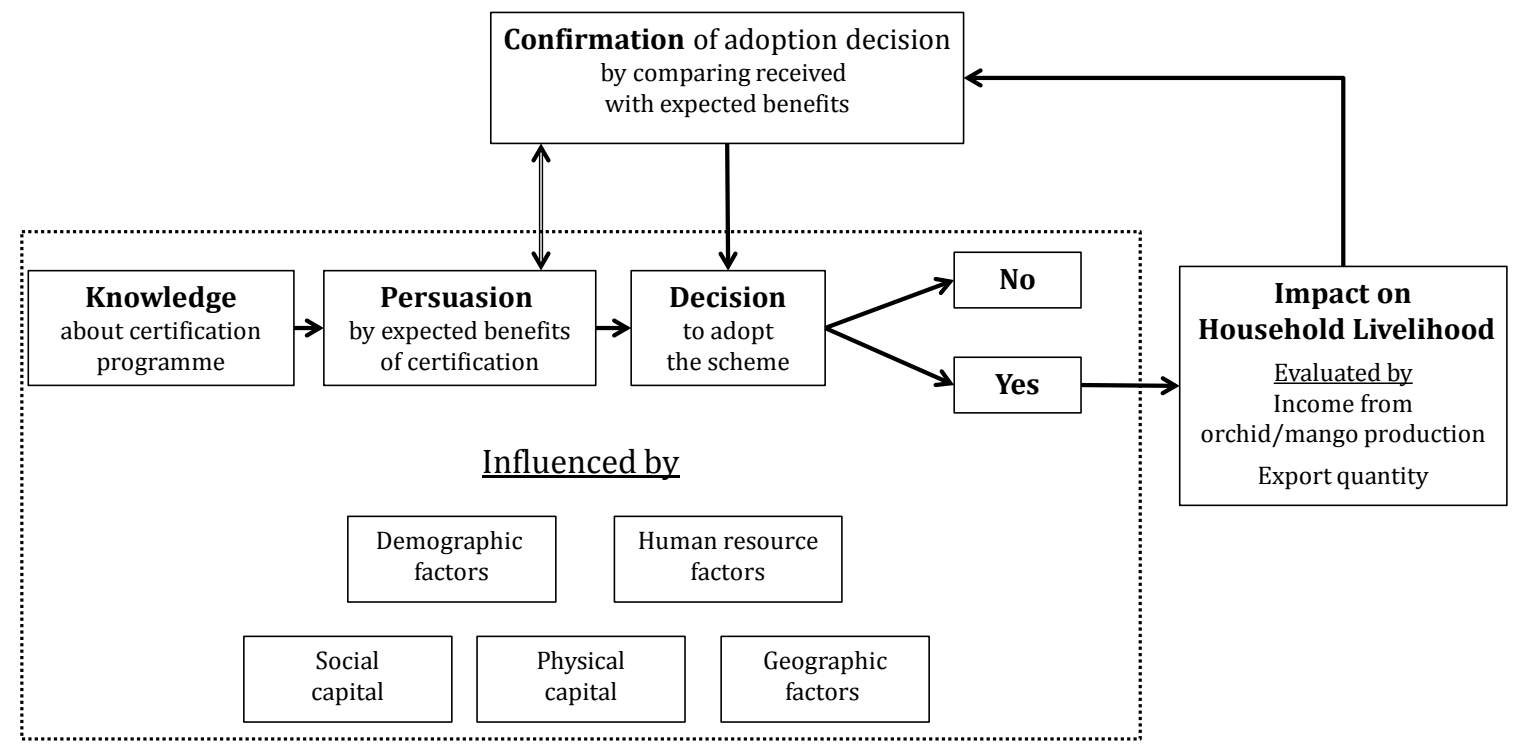

Figure 1. Relation between impact of certification and decision process towards certification. Source: Own picture based on $[29,32]$. 


\subsection{Choice of Variables for Adoption Model}

Age and gender of the household head are included as demographic factors (Table 1). Research found a significant influence of age on the decision to become Fairtrade certified in the Latin American banana and coffee sector, although the direction of influence was positive in some cases and negative in others [34-36]. For Thai small-scale fruit and vegetable producers, age had a negative influence on the decision to adopt GLOBALG.A.P. [37]. A male household head had a positive influence on adopting a geographical identification for Thai Jasmine rice [33]. They see reasons for these findings in the more dominant behavior and faster decision making of male household heads. Another variable included as a demographic factor is the household size, which had a positive influence in the case of geographical identification adoption [33] and for Kenyan vegetable producers adopting EurepGAP certification [38].

Table 1. Variables used for the choice model with expected signs.

\begin{tabular}{|c|c|c|c|c|}
\hline Group & Variable & Description & Expected Signs & Sources \\
\hline \multirow{3}{*}{$\begin{array}{l}\text { Demographic } \\
\text { factors }\end{array}$} & Age & Age of HH head & $+/-$ & [34-38] \\
\hline & Gender & Gender of HH head (binary: 1 = female) & - & [33] \\
\hline & Household size & Number of nucleus household members & + & {$[33,38]$} \\
\hline \multirow{2}{*}{ Human resources } & Education & years of formal education of $\mathrm{HH}$ head & + & {$[20,39,40]$} \\
\hline & Farming experience & years of experience in orchid/mango cultivation & + & {$[27,29,39]$} \\
\hline \multirow{2}{*}{ Physical capital } & Agricultural assets & Total value of agricultural assets (THB) & + & {$[20,25]$} \\
\hline & Land under main crop & Area under orchid/mango cultivation (rai) & + & {$[27,38,41]$} \\
\hline \multirow{2}{*}{ Social capital } & Producer group & $\begin{array}{l}\text { producer group participation (binary: } 1=\mathrm{HH} \\
\text { head participates in at least one producer group) }\end{array}$ & + & {$[20,33]$} \\
\hline & $\begin{array}{l}\text { Know Q-GAP } \\
\text { from DoAE }\end{array}$ & $\begin{array}{l}\text { Respondent knows about Q-GAP certification } \\
\text { from DoAE (binary: } 1=\text { yes) }\end{array}$ & + & {$[20,39,40]$} \\
\hline $\begin{array}{c}\text { Public } \\
\text { infrastructure }\end{array}$ & Distance to next town & Distance to next town $(\mathrm{km})$ & - & [32] \\
\hline
\end{tabular}

$1 \mathrm{THB}=1$ Thai Baht $=0.026$ Euro (24 October 2016); 1 rai $=0.16$ hectare, DoAE $=$ Department of Agricultural Extension; $\mathrm{HH}=$ household.

As human resource indicators, years of formal education of the household head and experience in orchid or mango cultivation are included in the model. Higher levels of education of household heads had a positive influence on GLOBALG.A.P. adoption in Kenyan vegetable [20] and Peruvian mango production [39]. Years of experience of the household head also facilitated adoption in the Peruvian case. The formal education facilitated initial Q-GAP adoption of Thai rice producers in Ayutthaya Province [40]. Among coffee farmers in Chumphon Province in Thailand, years of formal education and cultivation experience positively influenced Q-GAP adoption [27]. Younger age, higher education and longer cultivation experience influenced adoption of VietGAP, a public GAP standard like Q-GAP, by Vietnamese vegetable producers [29]. This is why a positive influence of the human resource variables is expected.

High levels of agricultural assets [20,25] or area under main crop [38] show a positive influence on standard adoption in Kenya. Cultivation area was also positively correlated with adoption of Q-GAP among Thai coffee producers [27] and adoption of ChinaGAP among Chinese agricultural cooperatives [41]. Thus, agricultural assets and area under main crop are included in the choice model to cover the physical capital dimension of livelihood choices and are expected to have a positive influence on the adoption decision.

Group membership can be considered as a form of social capital, because it gives farmers access to a network of other farmers, thus facilitating the process of information spreading. This has been confirmed in the process of geographical identification adoption among Thai farmers [33], as well as for adoption of GLOBALG.A.P. certification by Kenyan vegetable producers [20]. In both cases, information about the certification scheme itself also had a positive influence on the adoption decision. This relation was also found in the case of Q-GAP adoption for Thai coffee producers [27] and 
VietGAP adoption for Vietnamese vegetable producers [29]. Thus, knowledge about the scheme is included as a binary variable, one of which being if the household received knowledge about the scheme from the Agricultural extension service. Access to extension services was positively related to GLOBALG.A.P. adoption among Peruvian mango producers [39] and to Q-GAP adoption among Thai rice producers [40].

\section{Data and Methodology}

\subsection{Data Collection}

Mango and orchid were chosen as representative of edible and inedible produce due to the important role in the Thai floricultural and horticultural sectors, respectively. Thailand is one of the leading export countries for tropical flowers, and the most commercial one is orchid. In 2015, the total harvested areas of orchids amounted to 22,169 rai ( $1 \mathrm{rai}=0.16 \mathrm{ha}$ ) with a total production quantity at 50,873 tons. Production quantity declined from 2010 to 2011 due to severe flooding events in the second part of 2011, having detrimental effects on local infrastructure and production facilities. Nevertheless, orchid is still the most important economic floricultural product of Thailand with an export value of 2716 million THB ( $1 \mathrm{THB}=0.026$ Euro (24 October 2016)) where $77 \%$ are cut fresh orchids, where $80 \%$ of export cut orchid flowers are the Dendrobium variety [42]. The price achieved for exporting cut orchids strongly depends on the destination. The average export price per $\mathrm{kg}$ in 2015 for cut orchid flower was around $84 \mathrm{THB}$ per kg. Thai cut orchids are appreciated in many parts of the world with the significant trade partners being Japan, USA, China, Italy, Russian Federation, India and the Netherlands [43]. Whereas orchid flower is considered as a common flower in the domestic market. They are mainly sold on local markets and often used for religious purposes in Thailand [44]. Due to the Free Trade Agreement under the Asian Economic Community (AEC), it is remarkable that the major import markets for Thai cut orchid flowers would be concentrated more in Asian countries, whereas the export rate to the USA and the European market would decline as a result of the global economic recession.

Mango is also one important economic produce in the Thai fruit sector. More than 100 mango varieties have been cultivated all over the country with a total harvested area amounting to 2.1 million rai and of the total production quantity at 3.1 million tons in 2015 [42]. At the same period, Thailand exported fresh mango of around 33,900 tons, valued at 1211 million THB [42]. Among these, Nam Dok Mai is one of the significant commercial varieties and is renowned in overseas markets due to its taste. The major importing markets of Thai fresh mango are concentrated in Asian countries, especially South Korean, Vietnam and Japan with an average export price at 35,723 THB per ton (Office of Agricultural Extension, 2015).

The cross-sectional data was collected at the household level, obtained from a stratified randomly sampled survey of 256 orchid producers. Initially, five provinces (Nakornpatom, Samutsakorn, Bangkok, Ratchaburi and Chonburi) were selected based on the intensity of production for both domestic and export markets as well as the number of certified national Q-GAP standard producers in the region in the major Thai orchid production areas. The main orchid genus cultivated as cut flower for export is dendrobium. Subsequently, all orchid producers in these provinces were stratified into three strata: certified Q-GAP, formerly certified Q-GAP and non-certified Q-GAP. The final sampling units were randomly selected from these groups (Table 2). Interestingly, almost a third of all interviewed orchid producers had not been recertified in the year of the study. Some of them did not want to continue with the certification; some of them could not be recertified because the Department of Agricultural Extension (DoAE) did not have enough capacities available for the auditing. To not lose the information but to nevertheless distinguish them from the producers that were still certified or never obtained the Q-GAP certification, the stratum "Formerly Q-GAP" has been introduced. For the analyses in this paper, only producers from the certified and non-certified strata have been used. 
Table 2. Number of interviewed producers in 2012.

\begin{tabular}{ccccc}
\hline \multirow{2}{*}{ Certifying Status } & \multicolumn{2}{c}{ Orchid } & \multicolumn{2}{c}{ Mango } \\
\cline { 2 - 5 } & Population & Sampling & Population & Sampling \\
\hline Q-GAP producers & 75 & 68 & 228 & 80 \\
Formerly Q-GAP producers * & 207 & 76 & - & - \\
Non Q-GAP producers & 868 & 112 & 4180 & 64 \\
Total & 1150 & 256 & 4408 & 144 \\
\hline
\end{tabular}

* Sample producers who belong to the formerly certified orchid producer group are the ones who used to be certified with the national Q-GAP standard but left certification during the time period of our field survey. Source of orchid/mango population numbers: Thai Department of Agricultural Extension (DoAE).

For the case of mangoes, Chachengsao province was chosen as the study area. It is one of the major mango producing provinces focusing on Nam Dok Mai (Mangifera indica L.), a variety especially produced for export. This variety is predominantly grown in the eastern part of Thailand due to suitable climate and soil conditions and low transportation costs due to the proximity to Bangkok [45]. Similar to orchids, the total population from all mango producing districts was stratified into certified Q-GAP and non-certified Q-GAP. In Chachengsao province there were no formerly certified mango producers who had left the scheme in the year of the study. Consequently, 144 mango producers were randomly selected from these strata (Table 2).

The data collection was conducted in 2012 by employing a structured questionnaire with the following six sections: land information, production, marketing, attitude towards Q-GAP standard, household socio-economic and additional section for training record, environmental concern, infrastructure, and borrowing. The questionnaire was translated into Thai language and pre-tested three times. In addition, local experts were consulted before the finalization. All enumerators were trained by the responsible researchers and practiced some interviews before the actual survey started. Overall, the producer survey for orchid and mango lasted around three months.

\subsection{Methodology}

\subsubsection{Adoption Model}

Two probit models were used to estimate the factors, which influence the adoption of Q-GAP among orchid and mango producers, respectively.

Let the binary variable $y_{t}$ be the dependent variable, being 1 if the household is certified and 0 otherwise. The conceptual framework showed that the farm decision maker's demographic factors, human resource factors, physical capital, social capital and public infrastructure have an influence on the adoption decision. According to decision theory $[33,46]$ the household will try to maximize its utility $U_{t}$, which is based on the socioeconomic characteristics discussed above and the characteristics of being certified or not. Thus, the farmer will choose to get certified with Q-GAP if the latent variable model $y_{t}^{*}=U_{1}-U_{0}>0$ and will reject certification if $y_{t}^{*}=U_{1}-U_{0} \leq 0$, ceteris paribus. If the socioeconomic characteristics are translated into covariates $x_{t}$, the latent variable $y_{t}^{*}$ can be written as the linear model

$$
y_{t}^{*}=x_{t}^{\prime} \beta+\varepsilon_{t}^{*}
$$

Thus, the probability of being certified can be written as

$$
P\left(y_{t}=1 \mid x_{t}\right)=P\left(y_{t}^{*}>0 \mid x_{t}\right) .
$$

and

$$
P\left(y_{t}=0 \mid x_{t}\right)=P\left(y_{t}^{*} \leq 0 \mid x_{t}\right)
$$

The covariates $x_{t}$ have the same direction of influence on $y_{t}^{*}$ as on $y_{t}$ [47]. 


\subsubsection{Propensity Score Matching (PSM)}

This study investigates the impact of Q-GAP certification on income from mango and orchid production and the share of mangoes and orchids sold to the export market. Since farmers choose by themselves whether they want to be certified or not, treated and untreated households are not randomly assigned and thus may differ systematically in certain household characteristics or resource endowments, which determined the decision to adopt the scheme. This problem is called selection bias [48,49] and may overlay the treatment effect [50].

PSM is a good tool to estimate treatment effects by reducing the selection bias. It is especially feasible in the case of certification, because there is already a well-established body of literature and empirical evidence available on the adoption of certifications in general. This prior knowledge allows building a selection equation, for which the Conditional Independence Assumption (CIA) holds [51]. Furthermore, PSM does not assume a certain functional form of the outcome equation [51] and treatment effects estimated by PSM are robust if the sample size is as small as in our case [52]

The basic idea of PSM in our case is to compare every certified orchid or mango producer with one or several uncertified producers with relatively similar characteristics. To evaluate the similarity of characteristics, the Propensity Score (PS) $p(X)$ is used as a balancing score, describing the probability of being certified given the observed characteristics $X$ [53]. $p(X)$ is the result of a binary choice model describing the probability of being certified or non-certified given the covariates $X$. The average effect of certification on the certified individuals would then be written as

$$
\operatorname{ATT}_{P S M}=E_{p(X) \mid C=1}(\operatorname{Imp} \mid C=1)=E[Y(1) \mid C=1, p(X)]-E_{1}[Y(0) \mid C=1, p(X)]
$$

The formula adopted from Caliendo and Kopeinig [54] shows that the Average Treatment Effect on the Treated (ATT) describes the expected impact $(\operatorname{Im} p)$ of certification only for certified growers. It is derived by subtracting the expected outcome they would have if they were not certified $(C=0)$ from the expected outcome if they were certified $(C=1)$, weighted by the probability $p(X)$ of being certified or not. To assure robustness of the results to the matching algorithm, three different algorithms were used and evaluated parallel to each other: nearest neighbor (NN) matching with replacement, radius matching and kernel matching. Optimal bias reduction in caliper matching is reached with a caliper equaling to a fifth of the propensity score's standard deviation [55] and is thus set at 0.062 for orchid and 0.042 for mango. The bandwidth for Kernel matching was set to 0.05 for orchid and 0.2 for mango to ensure optimal bias reduction without too much loss of information. For a detailed discussion on the different algorithms, see [54].

In PSM, variance and thus standard errors of the ATT are overestimated, because it also includes the variance of the PS and common support estimation [56]. To reduce this problem, bootstrapped standard errors were used, where 500 repetitions are considered a good compromise between theory and practicability [57]. The ATT is only defined in the region of common support, in which all observations with the same covariates $X$ have a positive probability of being certified or not [53]. To ensure optimal bias reduction, the sample size was reduced by the observations within the areas of lowest PS distribution density (Table A3 in Appendix A) [58]. For the matching quality's evaluation, standardized bias and $t$-test of all covariates $X$ are investigated. Table A4 (Appendix A) shows that mean bias across all covariates could not be reduced to recommended levels of less than $5 \%$ after matching [54]. Due to a relatively small sample size, too rigid imposition of common support would have resulted in too high loss of information. However, Pseudo- $R^{2}$ 's approximating zero and insignificant $F$-test results indicate that there is no longer any significant difference between the covariates $[53,59]$. Thus, matching on the covariates can be considered successful with all three matching algorithms.

One major problem in PSM is the so-called hidden bias resulting from unobserved variables affecting both certification status and outcome. In this paper, this unobserved heterogeneity was investigated with Rosenbaum bounds [60]. Only statistically significant results were tested for 
sensitivity to hidden bias [61,62]. Table A5 (Appendix A) shows that the significant effects of Q-GAP certification among mango producers are very robust against hidden bias, since even a more than two times increase in hidden bias influence does not affect this significance.

To calculate the propensity score, the initial adoption model has been used in a slightly adapted form, because the covariates have to hold the Conditional Independence Assumption (CIA) to dedicate the differences in outcome clearly to the fact of being certified or not. They must not be influenced by the certification status, although they need to influence the participation decision and/or the outcome variable. Therefore, covariates need to be either fixed over time or measured before participation in the certification scheme [54]. The agricultural assets bought five years prior to the survey have been taken as an asset indicator, because Q-GAP certification was not fully implemented at that time and thus these assets are not influenced by Q-GAP certification. Furthermore, household size was taken out to prevent endogeneity with income per capita as outcome variable. Results of the adoption model for PSM can be found in Table A2 in Appendix A.

Additionally, the Heckman's two stage model has been estimated to confirm the PSM estimates. The choice models discussed above were used as the first stage (Appendix B). The reason for using Heckman as a robustness check is that we can include control variables in the second stage equation to rule out the influence of effects such as the floods that affected some orchid producing areas in the year of the survey.

\subsubsection{Outcome Variables}

The income from orchids and mango is directly calculated from the survey data. First, orchid/mango sales are calculated, multiplying the average price per unit of orchids or mango achieved by the farmer within the year of survey with the quantity sold. Farmers could state orchid sales in $\mathrm{kg}$ or stems and mango sales in $\mathrm{kg}$, but had to state the average price in the same unit (THB $/$ stem or $\mathrm{THB} / \mathrm{kg}$ ). From this sales figure, variable costs of labor, machinery and pesticide and fertilizer expenditures are deducted. To increase accuracy, these costs have been stated by the farmers for one representative plot from which they had best knowledge or most consistent records and subsequently calculated up to the overall area under orchid cultivation.

The export share is calculated as the share of the total sales of orchids and mangoes in THB, which was sold to buyers in the export market.

\section{Results and Discussion}

\subsection{Descriptive Results}

The demographic parameters do not differ substantially between orchid and mango producers (Table A1 in Appendix A). About a third of all household heads are female. The number of household members ranges in both crops around 4 , whereas certified orchid producers have significantly larger households than uncertified ones. More than two-thirds of both orchid and mango producers participate in producer groups. This share is significantly higher for certified producers of both crops. Almost a hundred percent of certified mango producers are in producer groups. Orchid producers seem to have more contact to the Department of Agricultural Extension, because a higher share of them heard about Q-GAP certification from this institution as compared to mango producers.

Orchid producers have a much higher annual income than the average mango producer, both in terms of total annual income and per capita income (Table 3). Because orchids are produced in greenhouses with very intensive production methods, it does not surprise that orchid producers' income per rai is much higher than the one from mango producers, who produce in orchards. Orchid producers also have higher levels of agricultural assets and sell substantially more of their products to the high-value and export market. Interestingly, these three indicators are significantly lower for uncertified mango producers compared to certified ones, while there is no significant difference between certified and uncertified orchid producers. Both certified mango and orchid producers employ 
more workers next to family workers, though the difference is not significant. The average daily wages paid are slightly higher among non-certified producers in both crops.

Table 3. Selected economic indicators of the sample.

\begin{tabular}{ccccccc}
\hline \multirow{2}{*}{ Variable } & \multicolumn{3}{c}{ Orchid } & \multicolumn{3}{c}{ Mango } \\
\cline { 2 - 7 } & Non-cert & Cert & Total & Non-cert & Cert & Total \\
\hline Annual household income & $1,979,539$ & $1,950,701$ & $1,968,537$ & $63,760 * * *$ & $1,332,287$ & 773,425 \\
(THB) & $(4,004,664)$ & $(2,779,954)$ & $(3,578,294)$ & $(369,905)$ & $(3,134,011)$ & $(2,433,825)$ \\
\hline \multirow{2}{*}{ Income per rai (THB) } & 185,682 & 156,986 & 174,671 & $4521 * * *$ & 17,949 & 12,033 \\
& $(335,227)$ & $(381,120)$ & $(352,721)$ & $(19,391)$ & $(35,267)$ & $(30,014)$ \\
\hline \multirow{2}{*}{ Income per capita (THB) } & 555,708 & 456,055 & 517,690 & $24,812 * * *$ & 325,741 & 193,164 \\
& $(1,086,166)$ & $(682,796)$ & $(951,630)$ & $(88,600)$ & $(688,997)$ & $(538,523)$ \\
\hline Share of products sold to & 0.649 & 0.682 & 0.662 & $0.012 * * *$ & 0.340 & 0.195 \\
export market & $(0.378)$ & $(0.342)$ & $(0.364)$ & $(0.062)$ & $(0.363)$ & $(0.319)$ \\
\hline \multirow{2}{*}{ Total value of assets (THB) } & 493,675 & 588,735 & 529,587 & $159,472 * * *$ & 479,215 & 338,349 \\
& $(491,718)$ & $(324,542)$ & $(437,601)$ & $(219,255)$ & $(397,984)$ & $(366,720)$ \\
\hline Land under orchid/mango & 16.76 & 17.41 & 17.01 & $15.88 * * *$ & 64.25 & 42.94 \\
cultivation (rai) & $(29.05)$ & $(15.37)$ & $(24.73)$ & $(20.84)$ & $(54.52)$ & $(49.24)$ \\
\hline Average number of & 5.3 & 10.3 & 7.2 & 5.0 & 7.7 & 6.7 \\
workers employed & $(19.7)$ & $(48.8)$ & $(33.8)$ & $(9.3)$ & $(8.4)$ & $(8.8)$ \\
\hline Average daily wage paid to & 516.56 & 455.15 & 489.69 & $372.58 *$ & 294.17 & 321.25 \\
workers (THB) & $(2754.86)$ & $(1876.30)$ & $(2402.72)$ & $(283.29)$ & $(170.19)$ & $(217.97)$ \\
\hline
\end{tabular}

Standard error in brackets, ${ }^{* * *}=$ significant at the $1 \%$-level, 1 rai and 0.16 ha.

When certified orchid and mango producers are asked about the advantages of Q-GAP certification, both orchid and mango producers mention better farm management as the major advantage of being certified (Figure 2). Some farmers said that, thanks to the required book keeping, they can handle inputs and calculate their costs better. These findings go along with an earlier study about Mangosteen producers under Q-GAP, who said that Q-GAP enhanced their farm management and reduced their input costs [26]. Vegetable producers following VietGAP certification came to the same statement [29].

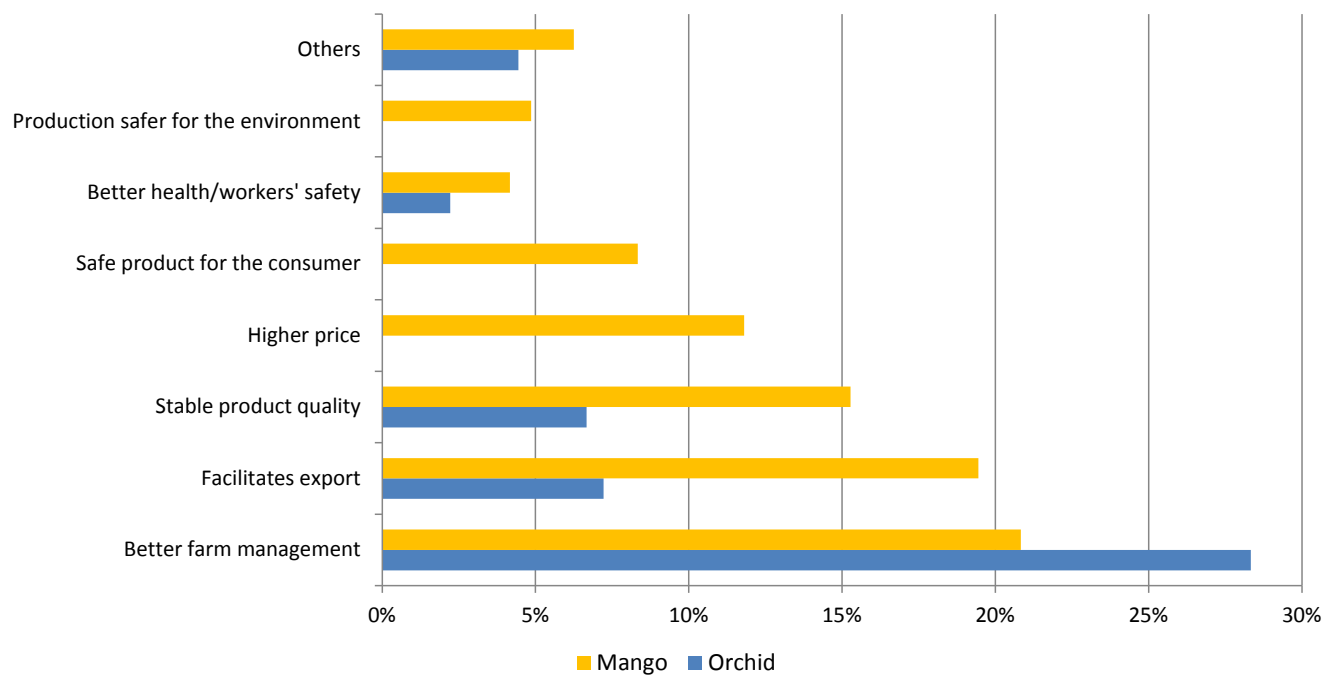

Figure 2. What do you consider as an advantage of Q-GAP? (open-ended question to all certified producers, answers grouped according to topics; multiple answers possible; $\mathrm{N}_{\text {orchid }}=68, \mathrm{~N}_{\text {mango }}=80$ ).

The other perceived advantages differ significantly between orchid and mango producers. Overall, mango producers find much more positive points to say about Q-GAP certification than orchid 
producers. Only around 7\% of orchid producers think that Q-GAP helps them to stable product quality and facilitate the export. Among mango producers, $19 \%$ and $15 \%$ consider this as an advantage. They also mention higher prices and that their products are safer for consumers and the environment - points that have not been mentioned by the orchid producers at all. Thus, while management related factors seem to be positively influenced by Q-GAP standards for both crops, only mango producers perceive a positive influence on product marketing and product safety.

One factor for this could be different customer demand for the different products. Since food safety is an ongoing issue in the Thai fresh horticultural market [3], producers of food crops would place more value on a certification scheme that enables them to fulfill higher food safety requirements. Furthermore, earlier findings on public GAP schemes suggest that producers of edible crops appreciate the increase in product safety and quality $[26,28,29]$. Orchid producers, on the other hand, may not have to pay attention to product safety at all. This is supported by the fact that the main reason for non-certified orchid producers to not get certified with Q-GAP was that exporters did not require the certification.

What are the real constraints that orchid and mango producers face when they want to produce for the high-value/export market? Figure 3 shows that challenges are quite different for orchid and mango producers. While the chemical residues on the product are the second most important constraint for mango producers, it is the least important for orchid producers. Since most orchids are used for decorative purposes, low levels of chemical residues play only a minor role as a sign of quality. Furthermore, orchid producers are less worried about their capability to comply with international standards as compared to mango producers.

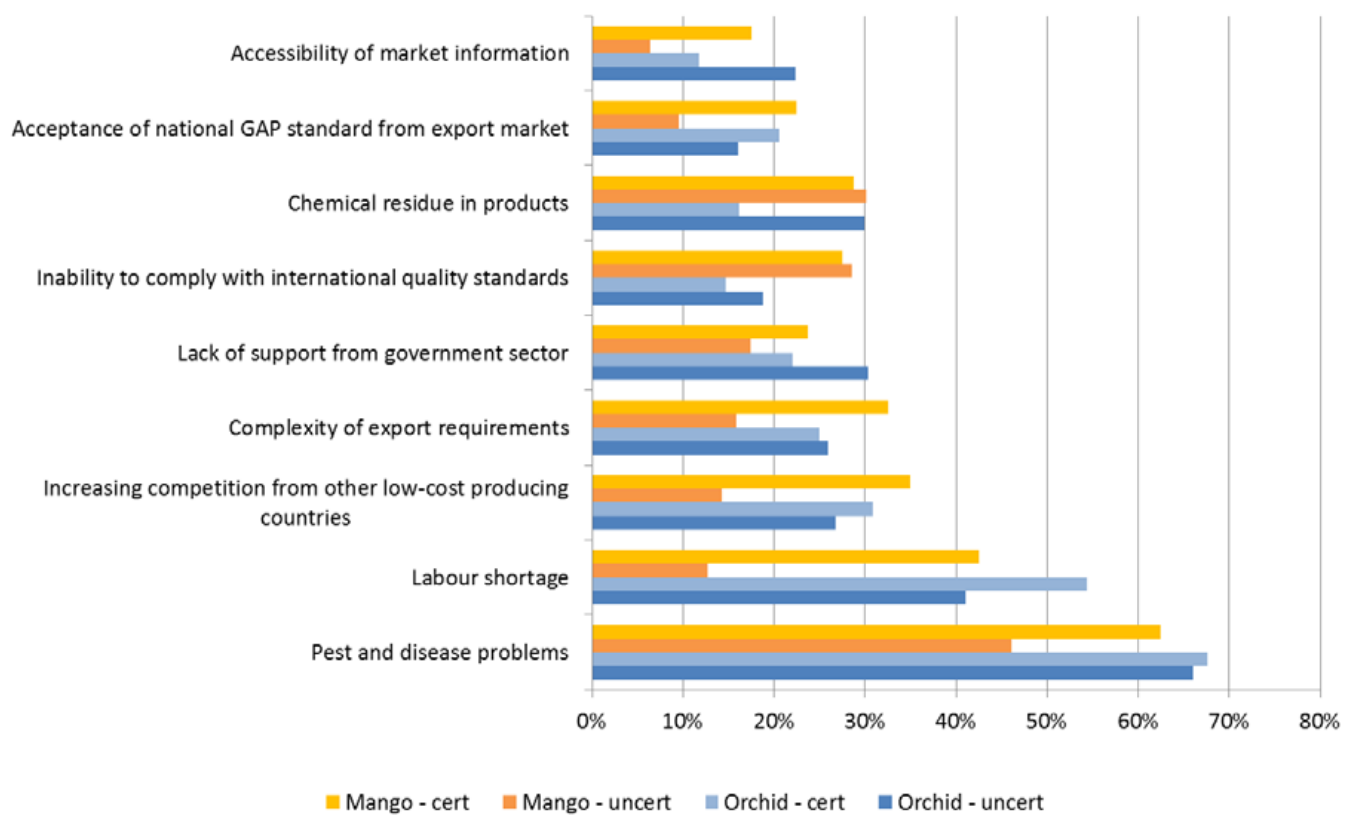

Figure 3. Main constraints to produce for/access the high-value export market (multiple answers possible; all producers, $\mathrm{N}_{\text {orchid }}=180, \mathrm{~N}_{\text {mango }}=144$ ).

About $30 \%$ of both certified and uncertified orchid producers consider the increasing competition from low-cost producing countries as a threat. Among mango producers, this share is much higher for certified producers than for uncertified ones. This could indicate that mango producers certified with Q-GAP hope to use the certification to differentiate their product in the market.

The most important aspects for both orchid and mango producers are pest and disease problems and labor shortage, while in both cases a higher percentage of orchid producers compared to mango producers see this as a major constraint. Certified mango producers consider this more often as an obstacle than uncertified ones, indicating that the certification makes pest and disease control 
more difficult as well as requiring more work. This confirms earlier research on the public VietGAP certification, where increased labor requirements due to the standard were a major hampering factor for adoption among litchi farmers [63].

\subsection{Factors Influencing the Adoption Decision of Q-GAP}

The estimated results of the binary probit are presented in Table 4 . The age of the household head, family size and gender have been included as demographic indicators, while the influence of the latter two are statistically insignificant for both mango and orchid producers. For the case of orchid, age of household head has an effect on the decision of Q-GAP adoption with the parabolic relationship indicated by the positive and negative significance of age and age square variables, respectively. This means that the older a farmer is, the more likely he or she is to certify, but with increasing age, this likelihood decreases again. The influence from age is significant at the $10 \%$ level. The same parabolic relation between age and household income was found in the case of coffee certification [47].

Table 4. Factors influencing the adoption of Q-GAP for mango and orchid producers.

\begin{tabular}{|c|c|c|c|c|c|}
\hline \multirow{2}{*}{ Group } & \multirow{2}{*}{ Variable } & \multicolumn{2}{|c|}{ Mango } & \multicolumn{2}{|c|}{ Orchid } \\
\hline & & Coef. & (SE) & Coef. & (SE) \\
\hline \multirow{4}{*}{ Demographic factors } & Age $\mathrm{HH}$ head & 0.187 & $(0.140)$ & $0.173 * *$ & $(0.067)$ \\
\hline & Age to the square & -0.002 & $(0.001)$ & $-0.001^{* *}$ & $(0.001)$ \\
\hline & Gender $\mathrm{HH}$ head & 0.239 & $(0.314)$ & -0.209 & $(0.242)$ \\
\hline & Household size & -0.050 & $(0.107)$ & 0.107 & $(0.071)$ \\
\hline \multirow{2}{*}{ Human resources } & Education $\mathrm{HH}$ head & 0.016 & $(0.049)$ & $0.054 * *$ & $(0.025)$ \\
\hline & Farming experience & -0.001 & $(0.014)$ & -0.011 & $(0.012)$ \\
\hline \multirow{2}{*}{ Physical capital } & Agricultural assets & $1.7 \times 10^{-6 * *}$ & $\left(6.7 \times 10^{-7}\right)$ & $3.8 \times 10^{-7}$ & $\left(2.7 \times 10^{-7}\right)$ \\
\hline & Land under main crop & $0.024^{* * *}$ & $(0.007)$ & -0.005 & $(0.005)$ \\
\hline \multirow{2}{*}{ Social capital } & Producer group & $1.311^{* * *}$ & $(0.363)$ & $0.809^{* * *}$ & $(0.220)$ \\
\hline & Know QGAP from DoAE & 0.601 & $(0.659)$ & $0.653^{* *}$ & $(0.259)$ \\
\hline \multirow{3}{*}{ Public infrastructure } & Distance to next town & 0.018 & $(0.012)$ & 0.011 & $(0.012)$ \\
\hline & Constant & $-7.502 *$ & $(3.925)$ & $-6.675^{* * *}$ & $(1.786)$ \\
\hline & Goodness of fit & \multicolumn{2}{|c|}{$\begin{array}{l}\text { Pseudo- } R^{2}: 0.4737 \text { Corr. } \\
\text { Classified: } 86.01 \%\end{array}$} & \multicolumn{2}{|c|}{$\begin{array}{l}\text { Pseudo- } R^{2}: 0.1710 \text { Corr. } \\
\text { Classified: } 71.67 \%\end{array}$} \\
\hline
\end{tabular}

se $=$ standard error, $\mathrm{HH}=$ household, ${ }^{*}=$ significant at the $10 \%$-level, ${ }^{* *}=$ significant at the $5 \%$-level, $* * *$ significant at the $1 \%$-level.

Years of formal education and years of experience in growing orchids or mangoes, respectively, are used to indicate human resource factors determining adoption. Both variables are not significant in the adoption decision of mango producers. For orchid producers, the years of formal education have a significant positive influence. This confirms earlier findings on public GAP standards that are easier adopted by farmers with higher education $[27,29]$ and goes along with results from GLOBALG.A.P. adoption among vegetable and mango producers in Kenya and Peru [20,43]. The distance to the next town as a proxy for public infrastructure did not have any significant influence.

While productive asset endowments, such as land and agricultural assets, have no significant effect on Q-GAP adoption for orchid producers, they have a significant positive influence in the case of mangoes. Higher land size has also been found as adoption influence for ChinaGAP [41] and among coffee producers for Q-GAP [27]. Furthermore, mango producers that were part of a producer group were significantly more likely to adopt certification. This positive influence of physical and social capital was also seen in earlier studies about private standards [20,35,42]. It shows that Q-GAP actually does not differ in the adoption patterns as compared to private standards. One advantage of Q-GAP is that it is free of charge and requirements are easier to accomplish than in private standards such as GLOBALG.A.P. and ThaiGAP, so that small farmers can also implement it [3]. At least for the case of mango and orchid production for export, it is still the better-educated, richer households that are getting certified. 


\subsection{Impact on Producers' Income and Export Shares}

The ATT in all three matching algorithms show a significant positive influence of Q-GAP certification on the overall household income and per capita income from mango producers (Table 5). The production efficiency in terms of income per rai also increases for certified mango producers, though this effect is only significant in one out of three matching algorithms. For orchid producers, however, Q-GAP certification does not have a significant influence on the income.

Table 5. Impact of Q-GAP certification on income and export share.

\begin{tabular}{cccccc}
\hline \multirow{2}{*}{ Variable } & \multirow{2}{*}{ Method } & \multicolumn{2}{c}{ Mango } & \multicolumn{2}{c}{ Orchid } \\
\cline { 3 - 6 } & & ATT & (SE) & ATT & (SE) \\
\hline \multirow{3}{*}{ Annual household income (THB) } & $\mathrm{N}$ & $995,855^{* * *}$ & $(331,337)$ & $-350,411$ & $(1,065,111)$ \\
& $\mathrm{R}$ & $1,014,486^{* * *}$ & $(348,456)$ & 512 & $(879,661)$ \\
& $\mathrm{K}$ & $1,059,040^{* * *}$ & $(322,164)$ & $-66,752$ & $(703,702)$ \\
\hline \multirow{3}{*}{ Income per rai (THB) } & $\mathrm{N}$ & 7512 & $(6923)$ & $-154,077$ & $(114,441)$ \\
& $\mathrm{R}$ & 9056 & $(5813)$ & $-33,090$ & $(87,826)$ \\
& $\mathrm{K}$ & $11,510^{* *}$ & $(5661)$ & $-35,251$ & $(76,418)$ \\
\hline \multirow{3}{*}{ Income per capita (THB) } & $\mathrm{N}$ & $248,989^{* * *}$ & $(82,953)$ & $-439,151$ & $(779,674)$ \\
& $\mathrm{R}$ & $250,226^{* * *}$ & $(77,727)$ & $-299,563$ & $(647,944)$ \\
& $\mathrm{K}$ & $258,532^{* * *}$ & $(78,993)$ & $-266,960$ & $(629,682)$ \\
\hline \multirow{3}{*}{ Share export/high-value market (\%) } & $\mathrm{N}$ & $29.75^{* * *}$ & $(5.17)$ & 4.65 & $(9.88)$ \\
& $\mathrm{R}$ & $30.30^{* * *}$ & $(5.31)$ & 0.03 & $(7.03)$ \\
& $\mathrm{K}$ & $30.69^{* * *}$ & $(4.95)$ & 1.01 & $(7.38)$ \\
\hline
\end{tabular}

ATT = Average treatment on the treated; SE = bootstrapped standard errors; ${ }^{* * *}=$ significant at the $1 \%$-level; $\mathrm{N}=$ Nearest Neighbor, Matching with replacement; $\mathrm{R}=$ Radius, Matching with caliper of 0.1 ; $\mathrm{K}=$ Kernel, Matching with bandwidth of 0.05 .

The insignificant influence of Q-GAP certification on orchid producers could be explained by the fact that Q-GAP certification does not facilitate orchid producers' access to the export market. All three matching algorithms in PSM and the Heckman model show no effect of Q-GAP certification on the share of sold value going to export. Descriptive results showed that orchid producers already sell about two-thirds of their harvest to the export market, showing that Q-GAP is not required in the orchid export sector. Earlier research also found that non-certified and certified orchid producers are using the same value chains [10]. In contrast, certified mango producers sell a significantly higher share of their product to high-value markets than uncertified ones. Another study on Thai Mangosteen producers leads to similar results: Q-GAP certification itself does not allow for a direct price premium, but it increased the share of high-quality fruits and is needed to enter the high-value export market, thus indirectly increasing farmers' income [26]. Thus, our study confirms earlier results that much of the income effect from the implementation of GAP standards is based on access to the high-value and export market [64].

The results of the PSM are supported by those of the second step Ordinary Least Squares (OLS) regression according to Heckman (Tables B1 and B2 in Appendix B). While the certification status has a positive influence on income and share of product sold to the export market for mango producers, it is insignificant on the outcomes for orchid producers. The influence of certification is even negative, though weakly significant, on orchid producers' income (Tables B1 and B2 in Appendix B).

Customers in Thai high-value retail and export are concerned about food safety, mainly due to end-customer concerns in Thailand and abroad. The reduction of food hazards in the domestic market and improvement of the image of Thai fresh produce in the export markets were among the major motivations of the Thai government to initiate Q-GAP [3]. While food safety plays an important role for fresh mangoes, it does not do so for orchids, because they are not an edible crop. In terms of food safety, the program indeed established certain credibility among Thai high-value retailers and middle-class end-customers [3]. Thus, the difference between the mango and the orchid case can be interpreted as a difference in how well the certification is already established as a brand in these crops in the Thai high-value and export market. 
Another reason for the insignificant influence of Q-GAP on orchid producers' income could be the effect of floods in the main orchid production area in 2011. To control for the effect of the flooding on individual households, it was included as a binary variable in the second stage OLS in the Heckman correction. Results indicate that being directly affected by the floods did not have a significant influence on income and export shares.

\section{Conclusions}

The present study evaluates the impact of voluntary public GAP standards on income and export shares of mango and orchid producers. Based on primary data from 400 certified and non-certified orchid and mango producers from the major exporting areas in Thailand, the binary probit model estimations show that the better-off orchid and mango producers in terms of education, physical and social capital tend to comply with Q-GAP standards. Compared to previous literature, there is no difference between the characteristics of horticultural adopters of private GAP schemes and this public GAP scheme. This study focuses on producers with export-oriented crops. Further study is necessary to evaluate the situation for the domestic market in order to get a full picture of the adoption patterns of Q-GAP.

The results of the impact models indicate that mango producers who comply with Q-GAP standards obtain a significantly higher net income than non-certified ones. For orchid producers, however, certification status did not have any influence on export quantities or income. It seems like the program is not designed to fit the needs of orchid producers. The Q-GAP certification focuses on pesticide reduction and compliance to international standards [3]. Our data shows that while these are indeed obstacles to access the export market for mango producers, these points are not an issue for orchid producers. They perceive the inability to comply with international standards as the least of their problems and none of the orchid producers perceived product safety or environmental protection as an advantage of the Q-GAP program. Instead, major obstacles to enter the export market, such as shortage of labor and pests and diseases on the product, are further worsened by the standard's requirements of record keeping and pesticide control. Nevertheless, a demand for excluding non-edible crops from Q-GAP certification might be premature. The case of VietGAP shows that producers actually gain from pesticide reduction because they significantly reduce the loss of income due to health hazards from pesticide handling [29]. This and the environmental benefits to reduce and ban certain pesticides are good reasons to continue the promotion of GAP standards in non-edible crops as well.

Conclusively, if Q-GAP was to be successful for non-edible horticultural crops, the certification needs to provide an additional value beyond product safety, which by itself is currently not remunerated by the buyers in international markets. The promotion of health benefits of following this standard for the farmer themselves could be one possibility to increase acceptance. Furthermore, since in the long run, Q-GAP seeks to be benchmarked to other international standards such as ASEAN-GAP or GLOBALG.A.P., producers already implementing this standard now may have an advantage in the future.

The major limitation of this study is that, so far, only cross-sectional data is available to gain insights into the certification's impact on producers' income. Even though two different established methods for impact analysis have been applied to check for robustness of the results, variation over time is not visible. An analysis based on panel data could reveal the real magnitude of impact and control better for hidden bias. While the analysis at hand showed clear differences between edible and non-edible horticultural crops regarding the adoption decision and impact of Q-GAP, further research is needed to understand the impacts of certification on other crops such as fresh vegetables for export. Furthermore, the mechanism as to why Q-GAP certified mango producers achieve higher income could be investigated with a follow-up study. Does Q-GAP enable the producers to access the high-value export market through better farm management and product safety, or did they adopt the certification simply to continue exporting, because exporters started to demand Q-GAP? Further research should 
also extend to other stakeholders in the value chain to understand their perception and expectations of Q-GAP, which could help the Thai government to ameliorate the scheme's performance further.

Acknowledgments: The authors would like to thank the Federal Ministry of Education and Research (BMBF) and the Federal State Ministries: Lower Saxony Ministry of Science and Culture, Brandenburg Ministry of Infrastructure and Agriculture and Bavarian Ministry of State of Science, Research and Art for financial support through the research program "Network of Excellence in Horticulture (WEGA)".

Author Contributions: Henning Krause, Rattiya Suddeephong Lippe and Ulrike Grote conceived and designed the experiments; Henning Krause and Rattiya Suddeephong Lippe performed the experiments; Henning Krause and Rattiya Suddeephong Lippe analyzed the data; Henning Krause, Rattiya Suddeephong Lippe and Ulrike Grote wrote the paper.

Conflicts of Interest: The authors declare no conflict of interest. The founding sponsors had no role in the design of the study; in the collection, analyses, or interpretation of data; in the writing of the manuscript, and in the decision to publish the results.

\section{Appendix A. Additional results and robustness checks for Propensity Score Matching}

Table A1. Selected household characteristics of the sample.

\begin{tabular}{ccccccc}
\hline \multirow{2}{*}{ Variable } & \multicolumn{3}{c}{ Orchid } & \multicolumn{3}{c}{ Mango } \\
\cline { 2 - 7 } & Non-Cert & Cert & Total & Non-Cert & Cert & Total \\
\hline \multirow{2}{*}{ Age HH head } & 49.04 & 51.15 & 49.83 & 54.48 & 54.85 & 54.69 \\
& $(12.32)$ & $(9.58)$ & $(11.38)$ & $(11.38)$ & $(9.48)$ & $(10.33)$ \\
\hline \multirow{2}{*}{ Gender HH head (1 = female) } & 0.321 & 0.221 & 0.283 & $0.413^{* *}$ & 0.250 & 0.322 \\
& $(0.469)$ & $(0.418)$ & $(0.452)$ & $(0.496)$ & $(0.436)$ & $(0.469)$ \\
\hline \multirow{2}{*}{ Number of HH members } & $4.18^{*}$ & 4.62 & 4.34 & 4.08 & 4.20 & 4.15 \\
& $(1.43)$ & $(1.56)$ & $(1.49)$ & $(1.56)$ & $(1.56)$ & $(1.56)$ \\
\hline \multirow{2}{*}{ Education HH head (year) } & 9.21 & 10.24 & 9.59 & 6.60 & 6.88 & 6.76 \\
& $(4.74)$ & $(4.93)$ & $(4.83)$ & $(3.67)$ & $(4.03)$ & $(3.86)$ \\
\hline \multirow{2}{*}{ Experience in orchid/mango production } & 19.91 & 20.78 & 20.24 & 19.57 & 22.10 & 20.99 \\
& $(9.50)$ & $(10.33)$ & $(9.80)$ & $(10.86)$ & $(11.12)$ & $(11.04)$ \\
\hline \multirow{2}{*}{ HH participates in producers group (1 = yes) } & $0.518^{* * *}$ & 0.765 & 0.611 & $0.460 * *$ & 0.938 & 0.727 \\
& $(0.502)$ & $(0.427)$ & $(0.489)$ & $(0.502)$ & $(0.244)$ & $(0.447)$ \\
\hline \multirow{2}{*}{ HH head knows QGAP from DoAE } & $0.134 * * *$ & 0.338 & 0.211 & $0.032 *$ & 0.113 & 0.077 \\
& $(0.342)$ & $(0.477)$ & $(0.409)$ & $(0.177)$ & $(0.318)$ & $(0.267)$ \\
\hline \multirow{2}{*}{ Distance to next town } & 10.03 & 11.40 & 10.55 & $11.61 *$ & 15.52 & 13.80 \\
& $(9.32)$ & $(8.17)$ & $(8.90)$ & $(10.43)$ & $(15.25)$ & $(13.44)$ \\
\hline
\end{tabular}

Standard error in brackets, ${ }^{*}=$ significant at the $10 \%$-level, ${ }^{* *}=$ significant at the $5 \%$-level, ${ }^{* * *}=$ significant at the $1 \%$-level, $\mathrm{HH}=$ household.

Table A2. Covariates for choice model to calculate the likelihood of being certified as propensity score.

\begin{tabular}{ccccc}
\hline \multirow{2}{*}{ Variable } & \multicolumn{2}{c}{ Mango } & \multicolumn{2}{c}{ Orchid } \\
\cline { 2 - 5 } & Coef. & (SE) & Coef. & (SE) \\
\hline Age HH head & $0.231^{*}$ & $(0.124)$ & $0.198^{* * *}$ & $(0.068)$ \\
Age to the square & $-0.002^{*}$ & $(0.001)$ & $-0.002 * *$ & $(0.001)$ \\
Gender HH head & -0.264 & $(0.270)$ & -0.163 & $(0.242)$ \\
Education HH head & 0.006 & $(0.044)$ & $0.066^{* *}$ & $(0.026)$ \\
Experience in farming & 0.012 & $(0.012)$ & -0.012 & $(0.013)$ \\
Assets bought 5 years ago & $0.000^{* * *}$ & $(0.000)$ & 0.000 & $(0.000)$ \\
Producer group & $1.486^{* * *}$ & $(0.315)$ & $0.764^{* * *}$ & $(0.222)$ \\
Know QGAP from DoAE & $1.045^{*}$ & $(0.557)$ & $0.657^{* *}$ & $(0.259)$ \\
Distance to next town & 0.011 & $(0.010)$ & 0.013 & $(0.012)$ \\
Constant & $-7.552^{* *}$ & $(3.524)$ & $-6.996^{* * *}$ & $(1.826)$ \\
\hline Goodness of fit & \multicolumn{2}{c}{ Pseudo $R^{2}: 0.3724$} & Pseudo $R^{2}: 0.2610$
\end{tabular}

$\mathrm{HH}=$ household, DoAE $=$ Department of Agricultural Extension, $\mathrm{SE}=$ standard errors, ${ }^{*}=$ significant at the $10 \%$-level, ${ }^{* *}=$ significant at the $5 \%$-level, ${ }^{* * *}=$ significant at the $1 \%$-level. 
Table A3. Imposition of common support in the different matching procedures.

\begin{tabular}{cccccc}
\hline \multirow{2}{*}{ Matching Algorithm } & \multicolumn{2}{c}{ Mango } & \multicolumn{2}{c}{ Orchid } \\
\cline { 3 - 6 } & & Off Support & On Support & Off Support & On Support \\
\hline \multirow{3}{*}{ NN } & Untreated & 9 & 54 & 1 & 106 \\
& Treated & 12 & 68 & 10 & 56 \\
& Total & 21 & 122 & 11 & 162 \\
\hline \multirow{3}{*}{ Radius } & Untreated & 9 & 54 & 4 & 103 \\
& Treated & 12 & 68 & 10 & 56 \\
& Total & 21 & 122 & 14 & 159 \\
\hline \multirow{3}{*}{ Kernel } & Untreated & 9 & 54 & 1 & 106 \\
& Treated & 12 & 68 & 10 & 56 \\
& Total & 21 & 122 & 11 & 162 \\
\hline
\end{tabular}

$\mathrm{NN}=$ Nearest Neighbor, Matching with replacement; Radius, Matching with caliper of 0.1; Kernel, Matching with bandwidth of 0.05 .

Table A4. Summary of bias reduction for the different matching algorithms.

\begin{tabular}{ccccc}
\hline Sample & Pseudo- $^{\mathbf{2}}$ & $\boldsymbol{F}$-Test & Mean Bias & Median Bias \\
\hline $\begin{array}{c}\text { Mango } \\
\text { (unmatched) }\end{array}$ & 0.333 & 0.000 & 37.0 & 29.9 \\
NN & 0.064 & 0.207 & 14.3 & 7.6 \\
Radius & 0.047 & 0.455 & 15.1 & 17.0 \\
Kernel & 0.031 & 0.755 & 9.8 & 11.1 \\
\hline Orchid & 0.155 & 0.000 & 23.1 & 19.1 \\
(unmatched) & 0.076 & 0.246 & 10.3 & 7.6 \\
$\quad$ NN & 0.017 & 0.980 & 11.9 & 12.6 \\
Radius & 0.015 & 0.986 & 9.5 & 7.1 \\
Kernel &
\end{tabular}

$\mathrm{NN}=$ Nearest Neighbor, Matching with replacement; Radius, Matching with caliper of 0.1; Kernel, Matching with bandwidth of 0.05 .

Table A5. Hidden bias increase (\%) until which results for mango producers remain significant at the $10 \%$-level.

\begin{tabular}{ccc}
\hline Outcome Variable & Matching Algorithm & \% \\
\hline \multirow{2}{*}{ Income per capita } & NN & 250 \\
& Radius & 270 \\
& Kernel & 300 \\
\hline \multirow{2}{*}{ Share of export market } & NN & 380 \\
& Radius & 380 \\
& Kernel & 370 \\
\hline
\end{tabular}

$\mathrm{NN}=$ Nearest Neighbor, Matching with replacement; Radius, Matching with caliper of 0.1; Kernel, Matching with bandwidth of 0.05 .

\section{Appendix B. Robustness Check with Heckman's Two-Stage Model}

The Heckman model addresses the selection bias by using an instrumental variable technique to remove the dependence of adoption on the welfare related variables [20]. The procedure of the Heckman model comprises (i) a selection equation and (ii) an outcome equation [20]. The selection equation is depicted as:

$$
c_{i}^{*}=\alpha X_{i}+u_{i} \quad u \sim N(0,1)
$$

$c_{i}^{*}$ is the latent variable for Q-GAP adoption. $c$ denotes the observable part of a dummy variable for Q-GAP adoption which $c=1$ if $c_{i}^{*}>0$ otherwise $c=0 . X_{i}$ denotes a vector of observed 
farm and non-farm characteristics determining Q-GAP adoption. The parameters in the selection equation are estimated using a probit regression for all observations. Based on the binary probit model, the correction-factor, the so-called "Inverse Mills Ratio (IMR)" is derived from the "univariate standard normal probability function" and the "cumulative distribution function" for each observation. The calculated IMRs are inserted in the second stage equations to test for potential selection bias. This is done through the coefficient of IMR testing the null hypothesis that there is no correlation between the error terms in Equations (B1) and (B2) [47].

$$
y_{O, M}=\beta_{0}+\beta_{1} c_{i}+\beta_{2} X_{i}+I M R+e_{i}
$$

$y_{O}$ denotes net income/share of product sold to export markets from orchid and $y_{M}$ from mango production, respectively. For the second stage, it reruns the regression with the primary interest to see whether Q-GAP adoption positively impacts on producers' income and share of product sold to export markets. Participation in a producer group is used as an exclusion restriction, because it strongly influences Q-GAP adoption, but does not have a significant influence on the outcome variables.

Table B1. Results Heckman two stage for mango.

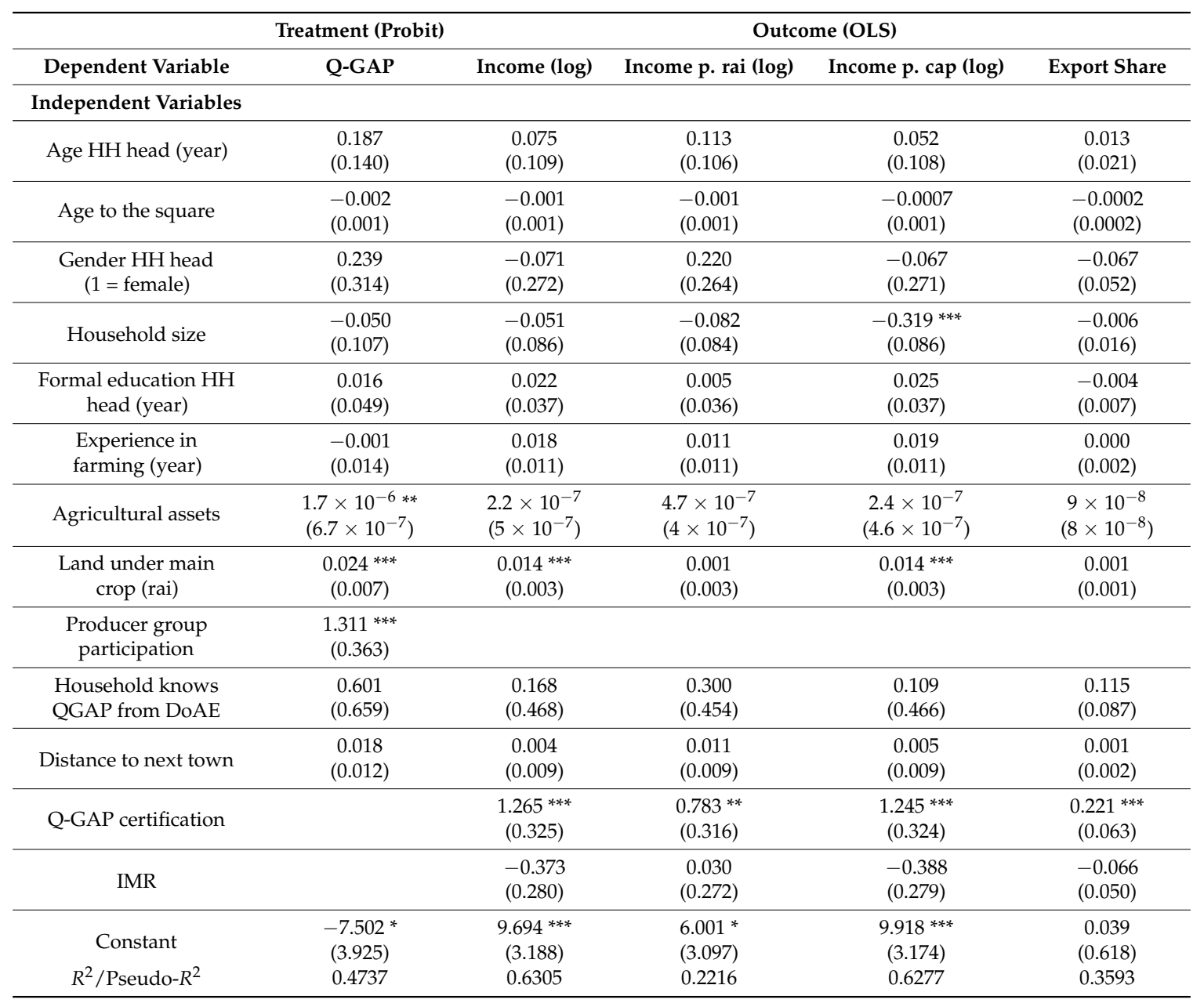

$\mathrm{HH}=$ household, DoAE = Department of Agricultural Extension, ${ }^{*}=$ significant at the $10 \%$-level, ${ }^{* *}=$ significant at the $5 \%$-level, ${ }^{* * *}=$ significant at the $1 \%$-level. 
Table B2. Results Heckman two stage for orchid.

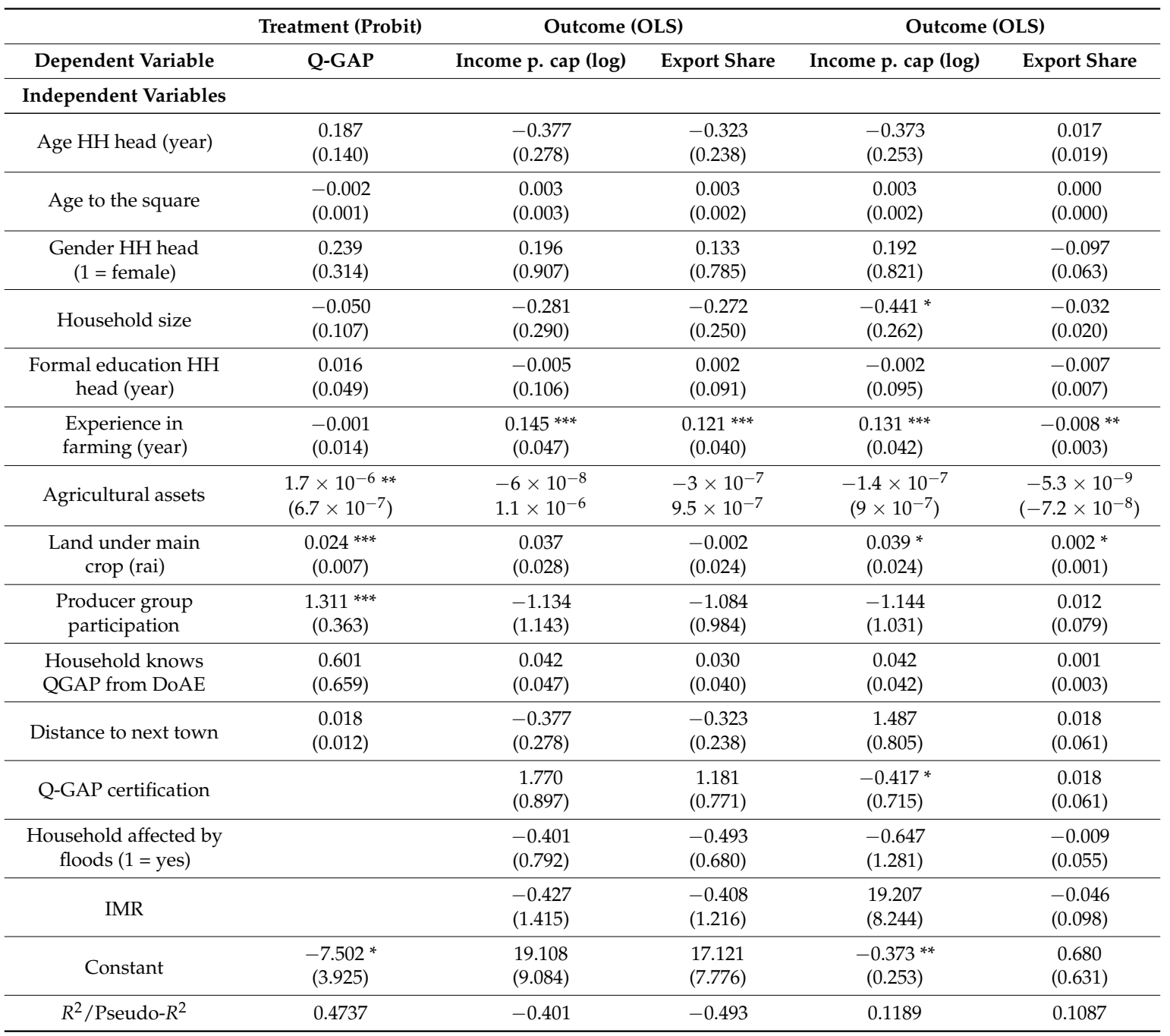

$\mathrm{HH}=$ household, DoAE $=$ Department of Agricultural Extension, ${ }^{*}=$ significant at the $10 \%$-level, ${ }^{* *}=$ significant at the $5 \%$-level, ${ }^{* * *}=$ significant at the $1 \%$-level.

\section{References}

1. Malorgio, G.; Felice, A. Trade and logistics: The fruit and vegetables industry. In MediTerra 2014: Logistics and Agro-Food Trade, A Challenge for the Mediterranean; Les Presses de Sciences Po: Paris, France, 2014; pp. 149-171.

2. European Commission Directorate General for Agriculture and Rural Development. Agricultural Commodity Markets Past Developments: Fruits and Vegetables. Available online: http:/ /ec.europa.eu/ agriculture/analysis/tradepol/worldmarkets/fruitveg/072007_en.pdf (accessed on 23 June 2016).

3. Wongprawmas, R.; Canavari, M.; Waisarayutt, C. A multi-stakeholder perspective on the adoption of Good Agricultural Practices in the Thai fresh produce industry. Br. Food J. 2015, 117, 2234-2249. [CrossRef]

4. Hatanaka, M.; Bain, C.; Busch, L. Third-party certification in the global agrifood system. Food Policy 2005, 30, 354-369. [CrossRef]

5. Gebreeyesus, M. Firm adoption of international standards: Evidence from the Ethiopian floriculture sector. Agric. Econ. 2015, 46, 139-155. [CrossRef]

6. Josling, T.; Roberts, D.; Orden, D. Food regulation and trade: Towards a safe and open global system. In Proceedings of the American Agricultural Economics Association Annual Meeting, Denver, CO, USA, 1-4 August 2004; Institute for International Economics: Washington, DC, USA, 2004.

7. Dankers, C. Environmental and Social Standards, Certification and Labelling for Cash Crops; Food and Agriculture Organization of the United Nations: Rome, Italy, 2003. 
8. Fuchs, D.; Kalfagianni, A.; Havinga, T. Actors in private food governance: The legitimacy of retail standards and multistakeholder initiatives with civil society participation. Agric. Hum. Values 2011, 28, 353-367. [CrossRef]

9. Food and Agriculture Organization of the United Nations (FAO). Incentive for the adoption of good agricultural practices. In FAO GAP Working Paper Series 3; Background Paper for the FAO Expert Consultation on a Good Agricultural Practice Approach; FAO: Rome, Italy, 2003.

10. Lippe, R.S.; Grote, U. Costs and Benefits of GAP Standards Adoption in Thai Horticulture. In Aktuelle Forschung in der Gartenbauökonomie, Proceeding of the 1st Symposium für Ökonomie im Gartenbau, Göttingen, Germany, 27 November 2013; Dirksmeyer, W., Theuvsen, L., Kayser, M., Eds.; Johann Heinrich von Thünen-Institut: Braunschweig, Germany, 2015; pp. 205-214.

11. Henson, S.; Jaffee, S. Understanding developing country strategic responses to the enhancement of food safety standards. World Econ. 2008, 31, 548-568. [CrossRef]

12. Henson, S.; Humphrey, J. Understanding the complexities of private standards in Global Agri-Food Chains as they impact developing countries. J. Dev. Stud. 2010, 46, 1628-1646. [CrossRef] [PubMed]

13. Giovannucci, D.P.; Sterns, P.A.; Eustrom, M.; Haantuba, H. The Impact of Improved Grades and Standards for Agricultural Products in Zambia; PFID-F\&V Report No. 3; Michigan State University and United States Agency for International Development: East Lansing, MI, USA, 2001.

14. Ouma, S. Global Standards, local realities: Private agrifood governance and the restructuring of the Kenyan Horticulture Industry. Econ. Geogr. 2010, 86, 197-222. [CrossRef]

15. Maertens, M.; Swinnen, J.F.M. Food standards, trade and development. Rev. Bus. Econ. 2009, 54, $313-326$.

16. Schreinemachers, P.; Schad, I.; Tipraqsa, P.; Williams, P.; Neef, A.; Riwthong, S.; Sangchan, W.; Grovermann, C. Can public GAP standards reduce agricultural pesticide use? The case of fruit and vegetable farming in northern Thailand. Agric. Hum. Values 2012, 29, 519-529. [CrossRef]

17. Wannamolee, W. Development of Good Agricultural Practices (GAP) for Fruit and Vegetables in Thailand; Office of Commodity and System Standards Accreditation; National Bureau of Agricultural Commodity and Food Standards: Bangkok, Thailand, 2008.

18. Department of Agricultural Extension; Bangkok, Thailand. Personal Communication, 2011.

19. Centre for Agricultural Information (CAI); Office of Agricultural Economics (OAE). Thailand Foreign Agricultural Trade Statistics 2014; Ministry of Agriculture and Co-operatives: Bangkok, Thailand, 2015.

20. Asfaw, S.; Mithöfer, D.; Waibel, H. What impact are EU supermarket standards having on developing Countries' export of high-value horticultural products? Evidence from Kenya. J. Int. Food Agribus. Mark. 2010, 22, 252-276. [CrossRef]

21. Bayramoglu, Z.; Gundogmus, E.; Tatlidil, F.F. The impact of EurepGAP requirements on farm income from greenhouse tomatoes in Turkey. Afr. J. Agric. Res. 2010, 5, 348-355.

22. Dörr, A.C.; Grote, U. Impact of certification on fruit producers in the Sao Francisco Valley in Brazil. Ann. Dunărea de Jos Univ. 2009, 15, 5-16.

23. Jenson, M.F. Developing New Exports from Developing Countries: New Opportunities and New Constraints. Ph.D. Thesis, The Royal Veterinary and Agricultural University, Copenhagen, Denmark, 2004.

24. Kersting, S. Adaptation of Smallholder Farmers to the Increasing Demand for Standards and Their Impacts-Case Study of the Horticultural Sector in Thailand. Diploma Thesis, University of Passau, Passau, Germany, 2009.

25. Okello, J.J. Compliance with International Food Safety Standards: The Case of Green Bean Production in Kenyan Family Farms. Ph.D. Thesis, Michigan State University, East Lansing, MI, USA, 2005.

26. Pongvinyoo, P.; Yamao, M.; Hosono, K. Cost efficiency of Thai National GAP (QGAP) and mangosteen farmers' understanding in Chanthaburi Province. Am. J. Rural Dev. 2015, 3, 15-23. [CrossRef]

27. Pongvinyoo, P.; Yamao, M.; Hosono, K. Factors affecting the implementation of Good Agricultural Practices (GAP) among Coffee Farmers in Chumphon province, Thailand. Am. J. Rural Dev. 2014, 2, 34-39. [CrossRef]

28. Nicetica, O.; van de Flierta, E.; Chienb, H.V.; Maic, V.; Cuongb, L. Good Agricultural Practice (GAP) as a vehicle for transformation to sustainable citrus production in the Mekong Delta of Vietnam. In Proceedings of the 9th European IFSA Symposium, Vienna, Austria, 4-7 July 2010.

29. Tran, H.B.C.; Le, T.Q.A. Impact of VietGAP Vegetable Production on the Health of Farmers Thua Thien Hue Province, Vietnam; EEPSEA Research Report No. 2015-RR19; Economy and Environment Program in Southeast Asia: Laguna, Philippines, 2015. 
30. Kleinwechter, U.; Grethe, H. The adoption of the Eurepgap standard by mango exporters in Piura. In Proceeding of the International Association of Agricultural Economists Conference, Gold Coast, Australia, 12-18 August 2006.

31. Rogers, E.M. Diffusion of Innovations, 5th ed.; The Free Press: New York, NY, USA, 2003.

32. Scoones, I. Sustainable Rural Livelihoods: A Framework for Analysis; IDS Working Paper 72; University of Sussex: Brighton, UK, 1998.

33. Ngokkuen, C.; Grote, U. Geographical indication for jasmine rice: Applying a logit model to predict adoption behavior of Thai farm households. Q. J. Int. Agric. 2012, 51, 157-185.

34. Fort, R.; Ruben, R. Impact of fair trade certification on coffee producers in Peru. In The Impact of Fair Trade; Ruben, R., Ed.; Wageningen Academic Publishers: Wageningen, The Netherlands, 2008; pp. 75-98.

35. Saenz-Segura, F.; Zuniga-Arias, G. Assessment of the effect of fair trade on smallholder producers in Costa Rica: A comparative study in the coffee sector. In The Impact of Fair Trade; Ruben, R., Ed.; Wageningen Academic Publishers: Wageningen, The Netherlands, 2008; pp. 117-135.

36. Zuniga-Arias, G.; Saenz-Segura, F. The impact of fair trade in banana production of Costa Rica. In The Impact of Fair Trade; Ruben, R., Ed.; Wageningen Academic Publishers: Wageningen, The Netherlands, 2008; pp. 99-116.

37. Kersting, S.; Wollni, M. New institutional arrangements and standard adoption: Evidence from small-scale fruit and vegetable farmers in Thailand. Food Policy 2012, 37, 452-462. [CrossRef]

38. Muriithi, B.W.; Mburu, J.; Ngigi, M. Constraints and determinants of compliance with EurepGap standards: A case of smallholder french bean exporters in Kirinyaga District, Kenya. Agribusiness 2011, 27, 193-204. [CrossRef]

39. Lemeilleur, S. Smallholder compliance with private standard certification: The case of GlobalGAP adoption by mango producers in Peru. Int. Food Agribus. Manag. Rev. 2013, 16, 159-180.

40. Srisopaporn, S.; Jourdain, D.; Perret, S.R.; Shivakoti, G. Adoption and continued participation in a public good agricultural practices program: The case of rice farmers in the central plains of Thailand. Technol. Forecast. Soc. Chang. 2015, 96, 242-253. [CrossRef]

41. Jin, S.; Zhou, J. Adoption of food safety and quality standards by China's agricultural cooperatives. Food Control 2011, 22, 204-208. [CrossRef]

42. Office of Agricultural Extension. Statistical Information on Agricultural Commodities; Office of Agricultural Extension: Bangkok, Thailand, 2015.

43. Thammasiri, K. Current status of orchid production in Thailand. In Acta Horticulturae 1078; Uthairatanakij, A., Wannakrairoj, S., Eds.; International Society for Horticultural Science (ISHS): Leuven, Belgium, 2015.

44. Lekawatana, S. Thai Orchid: Current situation. In Proceeding of the Taiwan International Orchid Symposium, Tainan, Taiwan, 5 March 2010; Flower and Ornamental Plant Production Promotion Group, Department of Agricultural Extension: Bangkok, Thailand, 2010.

45. Postharvest Technology Research Institute (PHTRI). Thai Mango's Value Chain Analysis and Supply Chain Management System to EU Markets; Final Report to The European Commission's Asia Invest Program "Integrated Supply Chain Management of Exotic Fruits from the ASEAN Region"; European Commission: Brussels, Belgium, 2009.

46. Dreier, J. Rational preference: Decision theory as a theory of practical rationality. Theory Decis. 1996, 40, 249-276. [CrossRef]

47. Wooldridge, J.M. Econometric Analysis of Cross Selection and Panel Data, 2nd ed.; The MIT Press: Cambridge, MA, USA, 2010.

48. Jena, P.R.; Chichaibelu, B.B.; Stellmacher, T.; Grote, U. The impact of coffee certification on small-scale producers' livelihoods: A case study from the Jimma Zone, Ethiopia. Agric. Econ. 2012, 43, 429-440. [CrossRef]

49. Blackman, A.; Rivera, J. Producer-Level Benefits of Sustainability Certification. Conserv. Biol. 2011, 25, 1176-1185. [CrossRef] [PubMed]

50. Heras-Saizarbitoria, I.; Molina-Azorín, J.F.; Dick, G.P.M. ISO 14001 certification and financial performance: Selection-effect versus treatment-effect. J. Clean. Prod. 2011, 19, 1-12. [CrossRef]

51. Bryson, A.; Dorsett, R.; Purdon, S. The Use of Propensity Score Matching in the Evaluation of Active Labour Market Policies; Her Majesty's Stationary Office: London, UK, 2002. 
52. Pirracchio, R.; Resche-Rigon, M.; Chevret, S. Evaluation of the Propensity score methods for estimating marginal odds ratios in case of small sample size. BMC Med. Res. Methodol. 2012. [CrossRef] [PubMed]

53. Rosenbaum, P.R.; Rubin, D.B. The central role of the propensity score in observational studies for causal effects. Biometrilca 1983, 70, 41-55. [CrossRef]

54. Caliendo, M.; Kopeinig, S. Some practical guidance for the implementation of propensity score matching. J. Econ. Surv. 2008, 22, 31-72. [CrossRef]

55. Austin, P.C. Optimal caliper widths for propensity-score matching when estimating differences in means and differences in proportions in observational studies. Pharm. Stat. 2010, 10, 150-161. [CrossRef] [PubMed]

56. Heckman, J.; Ichimura, H.; Todd, P. Matching as an econometric evaluation estimator. Rev. Econ. Stud. 1998, 65, 261-294. [CrossRef]

57. Lechner, M. Some practical issues in the evaluation of heterogeneous labour market programmes by matching methods. J. R. Stat. Soc. 2002, 165, 59-82. [CrossRef]

58. Smith, J.; Todd, P. Does matching overcome LaLonde's critique of nonexperimental estimators? J. Econom. 2005, 125, 305-353. [CrossRef]

59. Sianesi, B. An evaluation of the Swedish system of active labour market programmes in the 1990 s. Rev. Econ. Stat. 2004, 86, 133-155. [CrossRef]

60. Rosenbaum, P.R. Observational studies. In Springer Series in Statistics, 2nd ed.; Springer Science \& Business Media: New York, NY, USA, 2002.

61. Hujer, R.; Caliendo, M.; Thomsen, S.L. New evidence on the effects of job creation schemes in Germany-A matching approach with threefold heterogeneity. Res. Econ. 2004, 58, 257-302. [CrossRef]

62. Kassie, M.; Shiferaw, B.; Muricho, G. Adoption and impact of improved groundnut varieties on rural poverty. In Discussion Paper Series 10-11; The Environment for Development (EfD) Initiative: Gothenburg, Sweden, 2010.

63. Han, V.T.; Dung, N.M.; Santi, S. Litchi farmers' preference for the adoption of Vietnamese Good agricultural practices in Luc Ngan district, Vietnam. J. ISSAAS 2016, 22, 64-76.

64. Maertens, M.; Dries, L.; Dedehouanou, F.A.; Swinnen, J.F.M. High-value supply chains, food standards and rural households in Senegal. In Global Supply Chains, Standards and the Poor; Swinnen, J.F.M., Ed.; Catholic University of Leuven: Leuven, Belgium, 2007; pp. 159-172.

(C) 2016 by the authors; licensee MDPI, Basel, Switzerland. This article is an open access article distributed under the terms and conditions of the Creative Commons Attribution (CC-BY) license (http:/ / creativecommons.org/licenses/by/4.0/). 